\title{
Improving student expectations of learning in a problem-based environment
}

Citation for published version (APA):

Rovers, S. F. E., Clarebout, G., Savelberg, H. H. C. M., \& van Merrienboer, J. J. G. (2018). Improving student expectations of learning in a problem-based environment. Computers in Human Behavior, 87, 416-423. https://doi.org/10.1016/j.chb.2018.02.016

Document status and date:

Published: 01/10/2018

DOI:

10.1016/j.chb.2018.02.016

Document Version:

Publisher's PDF, also known as Version of record

Document license:

Taverne

Please check the document version of this publication:

- A submitted manuscript is the version of the article upon submission and before peer-review. There can be important differences between the submitted version and the official published version of record.

People interested in the research are advised to contact the author for the final version of the publication, or visit the DOI to the publisher's website.

- The final author version and the galley proof are versions of the publication after peer review.

- The final published version features the final layout of the paper including the volume, issue and page numbers.

Link to publication

\footnotetext{
General rights rights.

- You may freely distribute the URL identifying the publication in the public portal. please follow below link for the End User Agreement:

www.umlib.nl/taverne-license

Take down policy

If you believe that this document breaches copyright please contact us at:

repository@maastrichtuniversity.nl

providing details and we will investigate your claim.
}

Copyright and moral rights for the publications made accessible in the public portal are retained by the authors and/or other copyright owners and it is a condition of accessing publications that users recognise and abide by the legal requirements associated with these

- Users may download and print one copy of any publication from the public portal for the purpose of private study or research.

- You may not further distribute the material or use it for any profit-making activity or commercial gain

If the publication is distributed under the terms of Article $25 \mathrm{fa}$ of the Dutch Copyright Act, indicated by the "Taverne" license above, 


\title{
Improving student expectations of learning in a problem-based environment
}

\author{
Sanne F.E. Rovers*, Geraldine Clarebout, Hans H.C.M. Savelberg, \\ Jeroen J.G. van Merriënboer \\ Maastricht University, School of Health Professions Education, The Netherlands
}

\section{A R T I C L E I N F O}

\section{Article history:}

Received 9 August 2017

Received in revised form

2 February 2018

Accepted 15 February 2018

Available online 16 February 2018

\section{Keywords:}

Self-regulated learning

Problem-based learning

Expectations

Learning environments

Online tools

\begin{abstract}
A B S T R A C T
Despite the continuing popularity of problem-based learning ( $\mathrm{PBL}$ ) approaches in higher education worldwide, concerns have been raised regarding a decrease in effectiveness. Unrealistic expectations of students about the nature of learning in a PBL setting may lead to ineffective use of self-regulated learning strategies, in turn leading to suboptimal learning during self-study. In this study, we tested the effects of a workshop aimed at aligning students' perceptions and expectations of their learning environment to those of the university as expressed in faculty training programs. First-year PBL medical students were randomly assigned to either a control condition $(n=26)$ or a contrast (workshop) condition $(n=19)$, designed to enable them to compare and contrast their expectations to those of the university. Results showed no significant differences between conditions in students' reported use of SRL strategies, but indicated a differential development in students' intentions to take responsibility for their own learning, with students in the contrast condition reporting an increase in these intentions as a result of the intervention. The intervention did not have a differential effect for students with different pretest scores. We discuss how optimization of the PBL environment can inform the design of online, computerbased support tools.
\end{abstract}

() 2018 Elsevier Ltd. All rights reserved.

\section{Introduction}

Problem-based learning (PBL) is a comprehensive educational approach that is based on cognitive theories of learning (Dolmans, Wolfhagen, Van der Vleuten, \& Wijnen, 2001; Moust, Berkel, \& Schmidt, 2005). In a problem-based curriculum, students participate in small group tutorials, ideally consisting of 8-10 students. In these tutorials, students are presented with a problem or case, that is, a set of phenomena in need of explanation, designed to reflect problems from real-world professional practice. As learning is assumed to be context-specific (Pintrich, 1999), the goal is to enhance learning and transfer to professional practice by aligning the learning context with the future professional context (Könings, Brand-Gruwel, \& van Merriënboer, 2005). Furthermore, problems from "real" professional practice are assumed to enhance students' intrinsic interest in the subject matter (Schmidt, 1983; van den

\footnotetext{
* Corresponding author. Maastricht University, School of Health Professions Education, Universiteitssingel 60, PO Box 616, 6200 MD Maastricht, The Netherlands.

E-mail address: s.rovers@maastrichtuniversity.nl (S.F.E. Rovers).
}

Hurk, Wolfhagen, Dolmans, \& van der Vleuten, 1999b). Based on cognitive theories of learning, it is assumed that the discussions in the tutorial group also activate prior knowledge and promote elaboration, which facilitates learning (Dolmans et al., 2001).

Although many variations of PBL exist, all forms are based on problems as the foundation of learning, to be discussed in small groups in a self-directed, student-centered manner, with the teacher acting as facilitator of the group process rather than as an information transmitter or knowledge expert (Barrows, 1996).

Problem-based learning continues to be an important characteristic of higher education curricula across the world (Davidson, Major, \& Michaelsen, 2014; Moust et al., 2005; Yew \& Goh, 2016). Research indicates that the problem-based approach positively affects students' learning processes, as well as the outcomes of this learning. It has been shown to improve long-term retention of learning content (Strobel \& van Barneveld, 2009), deep learning and conceptual understanding (Berkson, 1993; Gijbels, Dochy, Van den Bossche, \& Segers, 2005), and skill development (Dochy, Segers, Van den Bossche, \& Gijbels, 2003; Kalaian, Mullan, \& Kasim, 1999; Vernon \& Blake, 1993). Additionally, problem-based learning has been shown to improve students' satisfaction with 
the curriculum (Colliver, 2000; Czabanowska, Moust, Meijer, Schröder-Bäck, \& Roebertsen, 2012; Newman, 2003). However, researchers have also indicated that at several universities the approach has become less effective over the years (Dolmans et al, 2001; Moust et al., 2005; Woltering, Herrler, Spitzer, \& Spreckelsen, 2009). Students seem to skip important aspects of the problem-solving process, going through the process in a routine manner without attempting to engage in deep learning (Moust et al., 2005).

Theoretically, one would assume that study time and selfregulation are important factors in explaining academic achievement. However, research has shown that time spent on self-study is not necessarily related to higher academic achievement (Kamp, 2013; van den Hurk et al., 1999b). Therefore, it might be more important to emphasize effective learning during self-study, rather than emphasizing the time spent on learning. Self-regulated learning (SRL) plays an important role in this process, and entails both motivational and cognitive processes (Boekaerts, 1997; Pintrich, Wolters, \& Baxter, 2000). SRL has been defined as the "process whereby students activate and sustain cognitions, behaviors and affects, which are systematically oriented toward attainment of their goals" (Schunk \& Zimmerman, 1994, p. 309). Because self-study takes place outside of the tutorial group, many details about this process, for example how students study, how they regulate their learning, and how this can be improved, remain unknown. Therefore, it is important to study this aspect of the PBL cycle and how it can be improved. When self-regulation and, by extension, deep study can be improved during this phase, students could acquire a deeper understanding of the content matter, enabling and motivating them to engage with this content more elaborately during the remainder of the process. This could be more successful than forcing them to go through the entire process in a static manner, which will not remediate and could even exacerbate the superficial processing. Rather, according to this reasoning, more effective self-regulation and self-study would naturally enhance processing in the other phases of the PBL process.

Although students have the ability to come up with their own "relevant" learning issues (i.e., learning issues that were intended by faculty members), these learning issues do not always guide the amount of time students spend on these topics, or their mastery of these issues, indicating that what students intend to do does not always correspond with what they actually do during self-study (Dolmans, Schmidt, \& Gijselaers, 1995). A reason for this could be that students in a PBL curriculum can feel uncertain about what they should study. As a result, they rely solely on peers and on resources that were suggested or prescribed by their teachers (Dahlgren \& Dahlgren, 2002; Dolmans \& Schmidt, 1994; Kivela \& Kivela, 2005; Lloyd-Jones \& Hak, 2004; van den Hurk et al., 1999b). In other words, instead of adhering to the self-defined learning issues, independently searching for literature to share with the group, and adopting strategies that facilitate deep learning (e.g. elaboration), students may exclusively use the literature provided by faculty members and use suboptimal learning strategies, such as memorizing.

In order to promote more effective self-study behavior, it could be important to enhance students' use of SRL strategies. PBL is considered to enhance SRL (Loyens, Magda, \& Rikers, 2008). However, students come to university with a set of expectations regarding learning in this new environment, which will influence how they approach this learning (Smith \& Wertlieb, 2005). There is a lack of alignment between the teacher-oriented methods students have become accustomed to in high school and those of university (Raidal \& Volet, 2008; Smith \& Wertlieb, 2005), a problem which could be exacerbated in the context of problembased learning, in which students are assumed to be active, self- regulated agents (Loyens et al., 2008). As students prefer to work according to their own learning habits (Könings et al., 2005), this incongruence may cause them to fall back on non-problem based approaches during the self-study stage. In other words, students' expectations about their learning environment moderate the relationship between PBL and SRL, and creating a more realistic set of expectations could lead to an enhancement of SRL in students by means of two mechanisms. First of all, volition is considered to be an important aspect of SRL (Corno, 2001). When students understand what is expected from them in a PBL curriculum and why, they may be more willing to comply with these expectations and make an effort to self-regulate their learning. Second, Wedman's performance pyramid framework (Wedman, 2010) identified expectations as an important factor influencing performance in the workplace (Wedman \& Graham, 1998), a framework which has also been applied in education (Hardy \& Aruguete, 2014). In other words, in order to perform well on a certain process, it is important that individuals understand what is expected of them. As SRL is generally considered to be a teachable process (Schunk \& Zimmerman, 1998), improving these expectations could potentially improve students' SRL performance. Although PBL universities might offer an introduction to students about the method before or at the beginning of the first year, this may not be sufficient for students to completely grasp the concept.

Based on this reasoning, a workshop was developed in which students were queried about their perceptions and expectations regarding their learning environment, enabling them to contrast these to the expectations as formulated by the university in faculty training programs. The current study investigated whether students' expectations and self-regulated learning can be enhanced by aligning their perceptions and expectations about their PBL learning environment to those of the university by means of this workshop. On a basic level, the workshop could lead to more realistic perceptions and expectations in students about their learning environment. As intentions are an important precursor for behavior (Sutton, 1998; Webb \& Sheeran, 2006), this could provide a fruitful basis for the development of more effective SRL strategies, as this understanding could make students more inclined to make an effort to self-regulate their learning. Based on what is known about student learning, an intervention emphasizing active and collaborative learning would be most beneficial (e.g., Bonwell \& Eison, 1991; Johnson, Johnson, \& Smith, 1998). Therefore, we chose a workshop as the form of our intervention, to make sure students were actively engaged in the subject.

Furthermore, educational interventions may have a different effect on students with differing ability levels (Snow, 1989), which has been demonstrated for both cognitive abilities (e.g., Kanfer \& Ackerman, 1989) as well as for metacognitive constructs (e.g., McInerney, McInerney, \& Marsh, 1997). Experimental and quasiexperimental research in education is indicative of a "Matthew effect", suggesting a relative as well as an absolute advantage for participants with higher pretest scores on beneficial outcomes related to the intervention (Walberg \& Tsai, 1983). Specifically, the Matthew effect would predict students with high initial abilities to benefit more from educational interventions (e.g., Becker, 2013), as their initial abilities give them a fruitful basis to learn from. Therefore, we further investigated whether the interventional workshop described above would have a larger effect for students with higher values for SRL and more realistic perceptions and expectations about their learning variables at pretest, versus students with lower scores on these variables at pretest.

As described above, PBL includes collaborative problem-solving, face-to-face-discussion and self-study involving SRL. This study focuses on the self-study phase for two reasons. First of all, much attention has already been given to the collaborative, face-to-face- 
aspects of PBL (e.g., Dolmans et al., 2001; Kamp, Dolmans, Van Berkel, \& Schmidt, 2013; van Blankenstein, Dolmans, van der Vleuten, \& Schmidt, 2011). Second, effective learning in the selfstudy phase can positively influence the other phases of the PBL cycle, giving students the tools to have more fruitful discussions in the collaborative, face-to-face sessions (Azer, 2009).

In summary, the research questions addressed in this study were the following: (1) Can students' SRL strategies be enhanced by means of a workshop aimed at aligning their perceptions and expectations about their learning environment to those of the university, and (2) Do students with different prior levels for SRL and realistic perceptions and expectations benefit differentially from this intervention? Our hypotheses are the following: Students who participated in the workshop will develop more realistic perceptions and expectations about their learning environment than students who did not participate in the workshop (H1a). Students who participated in the workshop will develop more effective SRL strategies than students who did not participate in the workshop (H1b). Students with more realistic perceptions and expectations about their learning environment at pretest will benefit more from the workshop than students who had less realistic perceptions and expectations (H2a). Finally, students reporting more effective SRL strategies at pretest will benefit more from the workshop than students reporting less effective SRL strategies (H2b).

\section{Methods}

\subsection{Participants, setting and design}

The design used for this study was a pretest-posttest control group design taking place over the duration of a four-week firstyear undergraduate Medicine course at a PBL university. It included first-year students from the Medicine undergraduate program.

Initially, 79 students started the pretest. A total of 45 students (Mean age $=19.30, \mathrm{SD}=.81,95.6 \%$ female) participated in the intervention and completed all measures, which constituted our final sample. The distribution of gender indicates an overrepresentation of females in the sample, but this was not surprising given the overrepresentation of female students in the program (71.2\% female).

Prior to the pretest, students were randomly assigned to either a contrast or a control condition. Three workshops were given, each aiming at 10 participants per workshop. However, due to drop-out the workshops became somewhat smaller, consisting of six, seven and seven participants respectively. Ultimately, 19 students from the contrast condition and 26 students from the control condition completed the posttest.

\subsection{Materials}

Two constructs were of interest to the present study: students' perceptions and expectations about their learning environment, and students' use of SRL strategies. We attempted to enhance these constructs by providing students with a workshop enabling them to compare and contrast the expectations they have regarding their learning environment to those of the university. The instruments used to measure these constructs and the workshop that was provided to students are described below.

\subsubsection{Perceptions and expectations $\uparrow$}

To measure students' perceptions and expectations regarding their learning environment, we used the Perceptions and Expectations about College Questionnaire (PEEK; Weinstein, Palmer, \& Hanson, 1995). This 30-item questionnaire measures students' convictions, thoughts, feelings and expectations about their learning environment at university and consists of three subscales: Academic Expectations, Personal Expectations and Social Expectations. Responses were collected using a 5-point Likert scale ranging from 1 (not at all likely to be part of university experience) to 5 (extremely likely to be part of university experience). Although no psychometric information has previously been published, this questionnaire was used in previous research (Krallman \& Holcomb, 1997) and has been recommended for the measurement of affective (non-cognitive) factors in educational research (Boylan, 2009; Robinson, Burns, \& Gaw, 1996).

For the current study, we only included the two subscales measuring Academic Expectations and Personal Expectations. The subscale measuring Social Expectations assesses students' expectations regarding social relationships with peers, (former) friends and family. It is not related to learning and therefore, it was irrelevant to the current research questions. For this reason, this subscale was not included in the study.

The Academic Expectations subscale measures students' cognitive expectations about the nature of learning and instruction, emphasizing responsibilities of students versus teachers in terms of keeping track of the learning process. Higher scores on this scale indicate students consider themselves less responsible for their own learning progress. For this subscale, item 10 had to be reversed.

The Personal Expectations subscale measures students' intentions to take responsibility for their own progress, with higher scores indicating a greater intention to this responsibility. For this subscale, items 3, 7 and 9 had to be reversed. Please refer to Krallman and Holcomb (1997) for a complete overview of the scales and items.

\subsubsection{Self-regulated learning}

To measure SRL, we used the scales recommended by Wolters, Pintrich, and Karabenick (2003) for measuring academic selfregulation. This questionnaire consists of 103 items measuring the cognitive, affective and behavioral strategies students apply to regulate their learning. Although appeals have been made for more behavioral measures of SRL (e.g., Winne, 2010), previous research has shown that a validated questionnaire can be sensitive enough to detect changes in SRL (Zimmerman, 2008).

Responses to the questionnaire were given on a 7-point Likert scale ranging from 1 (not at all true of me) to 7 (very true of me). The questionnaire consists of three scales: Regulation of Academic Cognition, Regulation of Motivation, and Regulation of Academic Behavior. The Regulation of Academic Cognition scale (Pintrich, Smith, Garcia, \& McKeachie, 1991, 1993) measures the cognitive strategies students use to regulate their learning, and consists of the subscale Rehearsal, Organization, Elaboration and Metacognitive Self-Regulation. The Regulation of Motivation scale (Wolters \& Rosenthal, 2000; Wolters, 1998) measures the affective strategies students use to regulate their learning when they are experiencing motivational problems and consists of the subscales Mastery SelfTalk, Relevance Enhancement, Situational Interest Enhancement, Performance/Relative Ability Self-Talk, Performance/Extrinsic Self-Talk, Self-Consequating, and Environmental Structuring. The Regulation of Academic Behavior scale measures the behavioral strategies used by students to regulate their learning. It consists of the subscales Effort Regulation (Pintrich et al., 1991, 1993), Regulation of Time and Study environment (Pintrich et al., 1991, 1993), General Intention to Seek Needed Help, General Intention to Avoid Needed Help, Perceived Benefits of Help Seeking, Perceived Costs of Help Seeking, Instrumental Help Seeking, Executive Help Seeking, Seeking Help from Formal Source, Seeking Help from Informal Source, and Perceived Teacher Support of Questioning (Karabenick \& Sharma, 1994).

Following recommendations by Wolters et al. (2003), we used 
the three scales as indicators of self-regulated learning strategies, with the exception that Rehearsal was dropped from the Regulation of Academic Cognition scale, as we consider rehearsal to be a surface rather than a deep learning strategy (Biggs, 1987). Furthermore, the subscales General Intention to Avoid Needed help, Perceived Costs of Help Seeking and Executive Help Seeking were reversed in order to obtain a similar direction of scores for all scales. The reader is referred to Wolters et al. (2003) for a full description of the scales, subscales and items.

\subsubsection{Workshop}

In the contrast condition, students participated in a workshop in which their perceptions and expectations regarding their learning environment were contrasted to the expectations as formulated by the university in the PBL faculty training programs. The workshop was led by the first and second author.

In this workshop, students were asked whether they had deliberately chosen to be in a PBL curriculum, what their expectations had been prior to starting the program, and the extent to which these prior expectations matched their actual experiences up to that point. The university uses a common script for organizing PBL tutorials, called the Seven-Jump (Moust et al., 2005), in which the following steps are used: (1) term clarification, (2) problem definition, (3) brainstorm, (4) identification of knowledge gaps, (5) formulation of learning issues, (6) self-study, and (7) discussion. These steps are based on a constructivist theory of learning, which assumes that understanding is facilitated by students' interacting with their environments, that learning is stimulated by cognitive conflict, and that knowledge is built through students' monitoring of their understanding of the subject matter (Dolmans et al., 2001; Savery \& Duffy, 1995). Students were asked to conduct a brainstorm in which they discussed, for each PBL step individually, their own and their tutor's role and responsibility in conducting this step and keeping track of the learning process. After this brainstorm, a comparison was made between their answers and the official expectations at the PBL university.

This workshop had previously been piloted among a small group of first-year Health Sciences students $(N=11)$, a population comparable in terms of faculty, study area and study year. In the pilot workshop, students went through all of the seven PBL steps in the same manner as described in the paragraph above. Results from this pilot study led us to put more emphasis on the defining, brainstorming, self-study and discussion steps of the PBL cycle, in contrast to the steps of clarification, identification of knowledge gaps and formulation of learning issues, as the former steps were found to show a higher discrepancy in terms of students' and university's perceptions and expectations.

\subsection{Procedure}

Written consent was obtained from all participants prior to data collection. Students were told the study aimed to investigate the factors influencing students' study behavior. Prior to the study, they were not informed that the workshop also aimed at improving this behavior. In the first week of the course, all participants were asked to complete an online questionnaire consisting of the PEEK and the SRL questionnaire. In the week following completion of the questionnaire, participants in the contrast condition participated in the workshop in order to align their perceptions and expectations to those of the university. Participants again completed the online questionnaire regarding their perceptions and expectations and their SRL level in the last week of the course. All participants were debriefed upon completion of the study, informing them about the purpose of the study. In this debriefing, students from the control group were offered the opportunity to take the same workshop after the experiment finished, in order to prevent the students from the workshop condition getting an unfair advantage in their education. Students were offered a small monetary reward for their participation in the study and were entered into a raffle to win an iPad mini. Table 1 shows a summary of the experimental design.

\subsection{Data analysis}

A Repeated Measures (RM) ANOVA was used to test whether the workshop led to differences in the development of students' perceptions and expectations and their use of SRL strategies. We chose the RM ANOVA over an ANCOVA, as we are interested in the difference in development on the variables for students over the duration of the block. As students partake in a range of mandatory educational activities as part of their enrolment in the PBL curriculum, it is quite conceivable that their SRL, as well as their perceptions and expectations of the learning environment, change as a function of their participation in the curriculum (Schmidt, Rotgans, \& Yew, 2011; van den Hurk, Wolfhagen, Dolmans, \& van der Vleuten, 1999a). Participation in the workshop is expected to change this natural development for students in the contrast condition, leading to a difference in slopes for students in the control condition versus students in the contrast condition. It is therefore necessary to take into account this differential development by including the within-subjects variability in the model (Field, 2009).

The within-subjects variables in this study were students' perceptions and expectations regarding their learning environment and their SRL level at pretest and posttest. Condition (contrast versus control) served as between-subjects variable. We were specifically interested in interaction effects between Session (pretest versus posttest) and Condition, as this would indicate a difference in improvement over time as a function of the intervention. Bonferroni correction was applied to account for analysis of multiple subscales, resulting in a significance value of $p=.05 / 10=.005$.

Furthermore, we were interested in whether effects would be different for students with different pretest scores on the five measures. To answer this question, we specified a regression analysis using the Condition and the pretest variable, as well as the interaction between Condition and the pretest variable as independent variables. The respective posttest variables were used as the dependent variable. If the interaction between Condition and pretest value is significant, this indicates that students with different pretest scores benefit differently from the workshop.

\section{Results}

\subsection{Reliability}

We used Cronbach's $\alpha$ to determine the reliability of the scales and subscales in the pretest and posttest. Cronbach's $\alpha$ values above .70 were considered to represent adequate reliability (Field, 2009). Due to the exploratory nature of this study and the psychological nature of the constructs measured, Cronbach's $\alpha$ values above .60 were still retained in the study (Field, 2009; Kline, 1999). Table 2 shows an overview of the reliability values found in this study. The SRL scales showed adequate reliability at both pre- and posttest. PEEK subscales showed acceptable to adequate reliability at

Table 1

Schematic overview of research design.

\begin{tabular}{llll}
\hline & PEEK + SRL & Workshop & PEEK + SRL \\
\hline Control $(n=26)$ & $\mathrm{X}$ & & $\mathrm{X}$ \\
Contrast $(n=19)$ & $\mathrm{X}$ & $\mathrm{X}$ & $\mathrm{X}$ \\
\hline
\end{tabular}


Table 2

Internal consistencies (Cronbach's $\alpha$ ) for the questionnaire scales.

\begin{tabular}{llll}
\hline & & Pretest & Posttest \\
\hline \multirow{2}{*}{ SRL } & Regulation of academic cognition & .783 & .806 \\
& Regulation of motivation & .846 & .924 \\
& Regulation of academic behavior & .881 & .870 \\
\multirow{2}{*}{ PEEK } & Academic expectations & .669 & .759 \\
& Personal expectations & .656 & .631 \\
\hline
\end{tabular}

both pre- and posttest and were therefore retained in the analysis.

\subsection{Workshop effects}

Table 3 shows descriptive statistics for the expectations and SRL measures included in the study. Results will be discussed according to the hypotheses outlined above.

\subsubsection{Hypothesis $1 a / 1 b$}

The repeated measures ANOVA revealed no significant interaction effect between Session and Condition for students' academic expectations regarding their learning environment ( $p$ 's $>.05$ ). However, there was a significant interaction effect between Session and Condition for students' personal expectations, Wilks' lambda $=.82, F(1,43)=9.52, p=.004, \eta_{\mathrm{p}}^{2}=.18$, indicating a differential development between conditions in students' intentions to take responsibility for their own learning. Inspection of the mean values indicates that students in the contrast condition improved their personal expectations, while there was no such improvement for students in the control condition. The partial eta squared value indicates a medium to large effect size, signaling that an important portion of the variance in personal expectations was explained by the provision of the workshop to the students in the experimental condition. The RM ANOVA revealed no significant interaction effects for students' reported use of SRL strategies ( $p$ 's > .05).

\subsubsection{Hypotheses $2 a / 2 b$}

To reveal a potential differential effect for students with different pretest scores for the five variables, we performed a regression analysis as described above. The regression weights for the interaction effects between condition and pretest scores were not significant ( $p$ 's $>.05$ ), indicating that all students benefited from the intervention in a similar manner. However, given the small standard deviations as indicated in Table 3, this could be due to a lack of pretest variation among students.

\section{Discussion}

This study tested the effectiveness of an intervention on the development of students' expectations and self-regulated learning strategies in the first-year Medicine undergraduate program at a PBL university. We expected that a better understanding of the university's expectations would make students more willing and able to comply and make an effort to self-regulate their learning (Corno, 2001; Wedman, 2010). Specifically, a PBL curriculum puts high demands on students in terms of initiative and self-regulated learning. Students are expected to proactively take initiative for their own learning, independently search for literature to construct their own knowledge, and make an active, conscious effort to achieve deep knowledge in collaboration with other students. The intervention consisted of a workshop in which students were given the opportunity to compare and contrast the expectations they had of their learning environment to the expectations as formulated by the university. It was hypothesized that students who participated in the workshop would develop more realistic expectations than students who did not participate in the workshop (H1a). Furthermore, these students were expected to develop more effective SRL strategies (H1b). Also, we expected students with more realistic perceptions and expectations about their learning environment at pretest to benefit more from the workshop than students who had less realistic perceptions and expectations at pretest (H2a), and students with more effective SRL strategies at pretest to benefit more from the workshop than students reporting less effective SRL strategies at pretest (H2b).

Hypothesis $1 \mathrm{a}$ was partly confirmed. We found that the intervention significantly improved students' personal expectations regarding their learning environment, indicating an increase in their motivation and preparedness to monitor and adjust their learning, but contrary to hypothesis $\mathrm{H} 1 \mathrm{~b}$, this did not lead to any significant changes in their reported use of self-regulated learning strategies. This is, however, an important finding, as this change in expectations could be a first step in the direction of an actual change in self-regulation, given the importance of intentions as a precursor for behavior (Sutton, 1998; Webb \& Sheeran, 2006).

Several implications can be derived from these results. Firstly, this study supports the value of active, collaborative ways of introducing students to the characteristics of learning environments in a PBL curriculum in terms of improving the expectations they have about their learning environment. Furthermore, although the intervention significantly improved students' personal expectations regarding their learning environment, indicating an increase in their motivation and preparedness to monitor and adjust their learning, we did not find significant changes in their reported use of self-regulated learning strategies. It is possible the current intervention was too short to have a lasting effect on students' use of self-regulatory strategies. Therefore, it is recommended that interventions be spread out over a longer period of time in order to have an effect on students' use of SRL strategies.

No support was found for Hypotheses $2 \mathrm{a}$ and $2 \mathrm{~b}$. We found no interaction between condition and students' pretest values in terms of perceptions and expectations or SRL strategy use, indicating that all students benefited from the intervention in a similar manner. This lack of interaction between condition and students' pretest levels indicates that all students benefited from the intervention in

Table 3

Descriptive statistics for the dependent variables.

\begin{tabular}{|c|c|c|c|c|c|c|}
\hline & \multicolumn{2}{|l|}{ Contrast } & \multicolumn{2}{|l|}{ Control } & \multirow[t]{3}{*}{$F$} & \multirow[t]{3}{*}{$p$} \\
\hline & Pretest & Posttest & Pretest & Posttest & & \\
\hline & $\mathrm{M}(\mathrm{sd})$ & $\mathrm{M}(\mathrm{sd})$ & $\mathrm{M}(\mathrm{sd})$ & $\mathrm{M}(\mathrm{sd})$ & & \\
\hline Personal expectations & $3.21(.45)$ & $3.41(.39)$ & $3.37(.54)$ & $3.29(.52)$ & 9.52 & .004 \\
\hline Academic expectations & $2.85(.34)$ & $2.82(.44)$ & $2.83(.56)$ & $2.71(.58)$ & .78 & .38 \\
\hline Cognition & $4.73(.56)$ & $4.88(.59)$ & $4.89(.62)$ & $5.10(.50)$ & .12 & .73 \\
\hline Motivation/Affect & $4.85(.48)$ & $4.94(.68)$ & $4.97(.59)$ & $5.17(.73)$ & .52 & .47 \\
\hline Behavior & $5.24(.58)$ & $5.17(.58)$ & $4.85(.63)$ & $5.03(.52)$ & 3.36 & .07 \\
\hline
\end{tabular}


a similar manner. An explanation for this finding can be found in the relatively small standard deviations associated with the variables, indicating little inter-individual variation in either perceptions and expectations or SRL strategy use. It is possible that an interaction would be found for groups of students with high interindividual variation on the variables at pretest (Speece, 1990). However, as the students in our sample scored in the middle range of the variables under investigation rather than predominantly in the lower end, this implies that most students will have something to gain from such an intervention. However, as this study was conducted with students who volunteered to participate, it is possible that students with less realistic expectations and lower use of SRL strategy use were not included in the study. Future research could target students at the more extreme ends of the spectrum, in order to investigate whether this lack of interaction is replicated, or whether the intervention is in fact more (or less) effective for students with lower (or higher) pretest aptitudes.

Regarding practical implications, a deeper understanding of the factors influencing the effectiveness of the PBL learning environment can help inspire tools to support SRL in such a curriculum. Like many educational programs nowadays, problem-based curricula often have a substantive online component, relying heavily on online learning resources such as BlackBoard. Optimizing the learning environment also opens up possibilities for the optimization of the online tools and resources that are offered to students to support their learning. For example, the online learning environment could incorporate a tool for students to compare and contrast their expectations and perceptions to those of the university, for example, concept mapping techniques with graph comparison (De Souza, Boeres, Cury, De Menezes, \& Carlesso, 2008) or a forum discussion. In this way, students are primed to think about the perceptions and expectations they have and are made aware about the extent to which this does or does not match the university's expectations. Furthermore, as the workshop was not sufficient for students to change their SRL strategies, tools could be incorporated to facilitate this transition. For example, the online learning environment could incorporate a tool that allows students to track their own progress. Examples include a tool that allows them to track how many hours they spend studying, as well as online quizzes to enable them to see how well they understand the material. In this way, students are enabled to translate their intentions to more concrete behavior. Finally, the workshop could be made more efficient by incorporating tools into the online environment that students can use prior to the intervention. When students use an online concept mapping tool to map their expectations prior to the intervention, the workshop time can be more efficiently used, potentially increasing its effectiveness.

Several limitations of this study should be noted. Firstly, our sample was comprised of students who volunteered to participate in the study, a limitation that is further underscored by the high dropout rate. It is quite likely that the students who started and persisted in the study were among the most motivated students in the program. Due to the novelty of this intervention, ethical considerations compelled us to first test it on a sample of students who were completely free in their choice about whether or not to participate. However, it is possible that the intervention's results would have been different when conducted across the entire program. Less motivated students may be more likely to benefit from the intervention. Alternatively, they could be less willing to cooperate, in which case the intervention would have little or no effect on them. Future research could focus on incorporating the intervention into the curriculum, thereby reaching all students who are enrolled in the program to come to a more complete picture of the effects of the intervention.

Furthermore, the use of self-reports for the measurement of SRL has become a topic of debate during the past couple of years (Veenman, Van Hout-Wolters, \& Afflerbach, 2006; Winne, 2010), with researchers indicating that students may not be reliable sources when reporting on their own SRL strategy use. However, as research shows that students have a tendency to underrate the occurrence of rare events, while overrating the occurrence of common events (Perry \& Winne, 2006), we feel that our results have probably not been influenced by the use of self-reports. More specifically, as this study dealt with common study events and the workshop likely primed students to focus more on their use of strategies, if anything this would have caused students in the contrast condition to overestimate their strategy use. Therefore, the likelihood of false positives, rather than false negatives, would be increased. However, the use of trace data is likely to give a more fine-grained, detailed picture of students' strategy use, enabling researchers to study students' SRL development throughout a course. Practical issues restrained us from using trace data in this study, but it is certainly recommended for further research and interventions in order to gain a more complete picture of students' development over time.

Third, our study used an active, collaborative workshop as an intervention to stimulate students to compare and contrast the expectations they have about their learning environment to those of the university. We chose this form based on what is known from the literature about student learning (e.g., Bonwell \& Eison, 1991; Johnson et al., 1998). However, sample size did not permit a comparison of this form of intervention to other forms of delivery, such as a traditional lecture. Future research could further inquire into which instructional format is most effective for the current intervention.

Finally, this study did not consider the perceptions and expectations of the tutors regarding students' learning process. As stated earlier, partly in response to students' negative attitudes, tutors often tend to adopt a teacher-oriented approach (Dolmans et al., 2001; Loyens et al., 2008; Moust et al., 2005). When confronted with a highly teacher-oriented tutor, students are not given the space to self-regulate their learning, even if they would be willing to do so. Future research should therefore look into the perceptions and expectations of tutors regarding students' learning environments and the effect this has on students' SRL both in and outside of the tutorial group, as well as focus on longer lasting interventions.

Given the continuing popularity of PBL in medical schools across the world, the importance of interventions to optimize the effectiveness of this educational approach is paramount. In order to successfully educate future professionals, the learning environment of students must be optimized as much as possible. The current study contributes to the literature by investigating an underexplored aspect of the PBL experience, namely the alignment between students' perceptions and expectations of the learning environment in comparison to those formulated by the university. Overall, this study shows the importance of aligning students' perceptions and expectations to the university in an active, collaborative manner, and opens up many interesting possibilities for online tools in learning and teaching.

\section{Conflicts of interest}

None. This research received no specific grant from any funding agency in the public, commercial or not-for-profit sectors.

\section{Acknowledgements}

The authors would like to thank Dr. Anique de Bruin for her invaluable feedback during the writing of this manuscript. 


\section{References}

Azer, S. A. (2009). Interactions between students and tutor in problem-based learning: The significance of deep learning. The Kaohsiung Journal of Medical Sciences, 25(5), 240-249.

Barrows, H. S. (1996). Problem-based learning in medicine and beyond: A brief overview. In L. Wilkerson, \& W. Gijselaers (Eds.), Bringing problem-based learning to higher education: Theory and practice. New directions for teaching and learning series (Vol. 68, pp. 3-11). San Francisco, CA: Jossey-Bass.

Becker, L. L. (2013). Self-regulated learning interventions in the introductory accounting course: An empirical study. Issues in Accounting Education, 28(3), 435-460.

Berkson, L. (1993). Problem based Learning: Have the expectations been met? Academic Medicine, 68(10), 79-88.

Biggs, J. B. (1987). Student approaches to learning and studying. Camberwell, Vic.: Australian Council for Educational Research.

van Blankenstein, F. M., Dolmans, D. H. J. M., van der Vleuten, C. P. M., \& Schmidt, H. G. (2011). Which cognitive processes support learning during small-group discussion? The role of providing explanations and listening to others. Instructional Science, 39(2), 189-204.

Boekaerts, M. (1997). Self regulated learning: A new concept embraced by researchers, policy makers, educators, teachers and students. Learning and Instruction, 7(2), 161-186.

Bonwell, C. C., \& Eison, J. A. (1991). Active Learning: Creating excitement in the classroom, 1991 ASHE-ERIC Higher Education Reports. Washington, D.C: The George Washington University, School of Education and Human Development.

Boylan, H. R. (2009). Targeted intervention for developmental education students (T.I.D.E.S.). Journal of Developmental Education, 32(3), 14-23.

Colliver, J. A. (2000). Effectiveness of problem based learning curricula - research and theory. Academic Medicine, 75(3), 259-266.

Corno, L. (2001). Volitional aspects of self-regulated learning. In B. J. Zimmerman, \& D. H. Schunk (Eds.), Self-regulated learning and academic achievement: Theoretical perspectives (2nd ed., pp. 191-226). Mahwah, NJ: Lawrence Erlbaum.

Czabanowska, K., Moust, J. H. C., Meijer, A. W. M., Schröder-Bäck, P., \& Roebertsen, H. (2012). Problem based learning revisited, introduction of active and selfdirected learning to reduce fatigue among students. Journal of University Teaching and Learning Practice, 9(1).

Dahlgren, M. A., \& Dahlgren, M. O. (2002). Portraits of PBL: Students' experiences of the characteristics of problem-based learning in physiotherapy, computer engineering and psychology. Instructional Science, 30(2), 111-127.

Davidson, N., Major, C. H., \& Michaelsen, L. K. (2014). Small-group learning in higher education-cooperative, collaborative, problem-based, and team-based learning: An introduction by the guest editors. Journal on Excellence in College Teaching, 25(3), 1-6.

De Souza, F., Boeres, M., Cury, D., De Menezes, C., \& Carlesso, G. (2008). An approach to comparison of concept maps represented by graphs. In Paper presented at the third international conference on concept mapping, Tallinn, Estonia \& Helsinki, Finland.

Dochy, F., Segers, M., Van den Bossche, P., \& Gijbels, D. (2003). Effects of problembased learning: A meta-analysis. Learning and Instruction, 13(5), 533-568. https://doi.org/10.1016/s0959-4752(02)00025-7.

Dolmans, D. H. J. M., \& Schmidt, H. G. (1994). What drives the student in problembased learning? Medical Education, 28(5), 372-380.

Dolmans, D. H. J. M., Schmidt, H. G., \& Gijselaers, W. H. (1995). The relationship between student-generated learning issues and self-study in problem-based learning. Instructional Science, 22(4), 251-267.

Dolmans, D. H. J. M., Wolfhagen, I. H. A. P., Van der Vleuten, C. P. M., \& Wijnen, W. H. F. W. (2001). Solving problems with group work in problem based learning - hold on to the philosophy. Medical Education, 35(9), 884-889.

Field, A. (2009). Discovering statistics using SPSS, London: Sage publications.

Gijbels, D., Dochy, F., Van den Bossche, P., \& Segers, M. (2005). Effects of problem-based learning: A meta-analysis from the angle of assessment. Review of Educational Research, 75(1), 27-61. https://doi.org/10.3102/00346543075001027.

Hardy, P., \& Aruguete, M. (2014). Needs assessment in STEM disciplines: Reliability, validity and factor structure of the student support needs scale (SSNS). Assessment \& Evaluation in Higher Education, 39(5), 553-562.

van den Hurk, M. M., Wolfhagen, I. H. A. P., Dolmans, D. H. J. M., \& van der Vleuten, C. P. M. (1999a). The impact of student-generated learning issues on individual study time and academic achievement. Medical Education, 33(11), 808-814.

van den Hurk, M. M., Wolfhagen, I. H. A. P., Dolmans, D. H. J. M., \& van der Vleuten, C. P. M. (1999b). Student-generated learning issues: A guide for individual study? Education and Health, 12(2), 213-221.

Johnson, D. W., Johnson, R. T., \& Smith, K. A. (1998). Cooperative learning returns to college what evidence is there that it works? Change: The Magazine of Higher Learning, 30(4), 26-35.

Kalaian, H. A., Mullan, P. B., \& Kasim, R. M. (1999). What can studies of problembased learning tell us? Synthesizing and modeling PBL effects on National Board of Medical Examination Performance: Hierarchical Linear Modeling meta-analytic approach. Advances in Health Sciences Education, 4(3), 209-221.

Kamp, R. J. A. (2013). Peer feedback to enhance learning in problem-based tutorial groups (PhD). Maastricht: Maastricht University.

Kamp, R. J. A., Dolmans, D. H. J. M., Van Berkel, H. J. M., \& Schmidt, H. G. (2013). The effect of midterm peer feedback on student functioning in problem-based tutorials. Advances in Health Sciences Education, 18(2), 199-213.

Kanfer, R. \& Ackerman, P. L. (1989). Motivation and cognitive abilities: An integrative/aptitude-treatment interaction approach to skill acquisition. Journal of Applied Psychology, 74(4), 657.

Karabenick, S. A., \& Sharma, R. (1994). Seeking academic assistance as a strategic learning resource. In P. R. Pintrich, D. R. Brown, \& C. E. Weinstein (Eds.), Student motivation, cognition, and learning: Essays in honor of Wilbert J. McKeachie (pp. 189-211). Hillsdale, NJ: Lawrence Erlbaum Associates.

Kivela, J., \& Kivela, R. J. (2005). Student perceptions of an embedded problem-based learning instructional approach in a hospitality undergraduate programme. International Journal of Hospitality Management, 24(3), 437-464.

Kline, P. (1999). The handbook of psychological testing (2nd ed.). London: Routledge.

Könings, K. D., Brand-Gruwel, S., \& van Merriënboer, J. G. (2005). Towards more powerful learning environments through combining the perspectives of designers, teachers, and students. British Journal of Educational Psychology, 75 645-660. https://doi.org/10.1348/000709905X43616.

Krallman, D., \& Holcomb, T. (1997). First-year expectations: Pre- and post- orientation. In Paper presented at the annual meeting of the association of institutional research, Buena Vista, FL.

Lloyd-Jones, G., \& Hak, T. (2004). Self-directed learning and student pragmatism. Advances in Health Sciences Education, 9, 61-73.

Loyens, S. M. M., Magda, J., \& Rikers, R. M. J. P. (2008). Self-directed learning in problem-based learning and its relationships with self-regulated learning. Educational Psychology Review, 20(4), 411-427. https://doi.org/10.1007/s10648008-9082-7.

McInerney, V., McInerney, D. M., \& Marsh, H. W. (1997). Effects of metacognitive strategy training within a cooperative group learning context on computer achievement and anxiety: An aptitude-treatment interaction study. Journal of Educational Psychology, 89(4), 686.

Moust, J. H. C., Berkel, H. J. M. V., \& Schmidt, H. G. (2005). Signs of erosion: Reflections on three decades of problem-based learning at Maastricht University. Higher Education, 50(4), 665-683. https://doi.org/10.1007/s10734-004-6371-z.

Newman, M. (2003). Special report 2: A pilot systematic review and meta-analysis on the effectiveness of problem based learning. Middlesex University, UK: ITSN Learning and Teaching Support Network.

Perry, N. E., \& Winne, P. H. (2006). Learning from learning kits: gStudy traces of students' self-regulated engagements with computerized content. Educational Psychology Review, 18(3), 211-228.

Pintrich, P. R. (1999). The role of motivation in promoting and sustaining selfregulated learning. International Journal of Educational Research, 31, 459-470.

Pintrich, P. R., Smith, D. A. F., Garcia, T., \& McKeachie, W. J. (1991). A manual for the use of the motivated strategies for learning questionnaire (MSLQ). Ann Arbor: National Center for Research to Improve Postsecondary Teaching and Learning, University of Michigan.

Pintrich, P. R., Smith, D. A. F., Garcia, T., \& McKeachie, W. J. (1993). Reliability and predictive validity of the motivated strategies for learning questionnaire (MSLQ). Educational and Psychological Measurement, 53(3), 801-813.

Pintrich, P. R., Wolters, C., \& Baxter, G. (2000). Assessing metacognition and selfregulated learning. In G. Schraw, \& J. Impara (Eds.), Issues in the measurement of metacognition (pp. 43-97). Lincoln, NE: Buros Institute of Mental Measurements.

Raidal, S. L., \& Volet, S. E. (2008). Preclinical students' predispositions towards social forms of instruction and self-directed learning: A challenge for the development of autonomous and collaborative learners. Higher Education, 57(5) 577-596. https://doi.org/10.1007/s10734-008-9163-z.

Robinson, D. A. G., Burns, C. F., \& Gaw, K. F. (1996). Orientation programs: A foundation for student learning and success. New Directions for Student Services, 75 55-68. https://doi.org/10.1002/ss.37119967507.

Savery, J. R., \& Duffy, T. M. (1995). Problem-based learning: An instructional model and its constructivist framework. Educational Technology, 35(5), 31-37.

Schmidt, H. G. (1983). Problem based learning: Rationale and description. Medical Education, 17, 11-16.

Schmidt, H. G., Rotgans, J. I., \& Yew, E. H. (2011). The process of problem-based learning: What works and why. Medical Education, 45(8), 792-806.

Schunk, D. H., \& Zimmerman, B. J. (1994). Self-regulation of learning and performance: Issues and educational applications. Hillsdale, NJ: Lawrence Erlbaum Associates, Inc.

Schunk, D. H., \& Zimmerman, B. J. (1998). Self-regulated learning: From teaching to self-reflective practice. New York, NY: Guilford Press.

Smith, J. S., \& Wertlieb, E. C. (2005). Do first-year college students' expectations align with their first-year experiences? NASPA Journal, 42(2), 153-174.

Snow, R. E. (1989). Aptitude-treatment interaction as a framework for research on individual differences in learning. In P. L. Ackerman, R. J. Sternberg, \& R. Glaser (Eds.), Learning and individual differences: Advances in theory and research ( $\mathrm{pp}$ 13-59). New York, NY: W.H. Freeman/Times Books/Henry Holt \& Co.

Speece, D. L. (1990). Aptitude-treatment interactions: Bad rap or bad idea? The Journal of Special Education, 24(2), 139-149.

Strobel, J., \& van Barneveld, A. (2009). When is PBL more effective? A metasynthesis of meta-analyses comparing PBL to conventional classrooms. Interdisciplinary Journal of Problem-Based Learning, 3(1). https://doi.org/10.7771 1541-5015.1046.

Sutton, S. (1998). Predicting and explaining intentions and behavior: How well are we doing? Journal of Applied Social Psychology, 28(15), 1317-1338.

Veenman, M. V. J., Van Hout-Wolters, B. H. A. M., \& Afflerbach, P. (2006). Metacognition and learning: Conceptual and methodological considerations. 
Metacognition and Learning, 1(1), 3-14. https://doi.org/10.1007/s11409-0066893-0.

Vernon, D. T. A., \& Blake, R. L. (1993). Does problem-based learning work? A metaanalysis of evaluative research. Academic Medicine, 68(7), 550-563.

Walberg, H. J., \& Tsai, S.-L. (1983). Matthew effects in education. American Educational Research Journal, 20(3), 359-373.

Webb, T. L., \& Sheeran, P. (2006). Does changing behavioral intentions engender behavior change? A meta-analysis of the experimental evidence. Psychological Bulletin, 132(2), 249-268.

Wedman, J. (2010). The performance pyramid. In R. Watkins, \& D. Leigh (Eds.), Handbook of improving performance in the workplace (pp. 51-80). San Francisco, CA: Wiley/Pfeiffer. Vol. 2: Selecting and implementing performance interventions.

Wedman, J., \& Graham, S. W. (1998). Introducing the concept of performance support using the performance pyramid. The Journal of Continuing Higher Education, 46(3), 8-20.

Weinstein, C. E., Palmer, D. R., \& Hanson, G. (1995). Perceptions, expectations, emotions and knowledge about college. Clearwater, FL: H\&H.

Winne, P. H. (2010). Improving measurements of self-regulated learning. Educational Psychologist, 45(4), 267-276. https://doi.org/10.1080/00461520.2010.517150.
Woltering, V., Herrler, A., Spitzer, K., \& Spreckelsen, C. (2009). Blended learning positively affects students' satisfaction and the role of the tutor in the problembased learning process: Results of a mixed-method evaluation. Advances in Health Sciences Education: Theory and Practice, 14(5), 725-738. https://doi.org/ 10.1007/s10459-009-9154-6.

Wolters, C. A. (1998). Self-regulated learning and college students' regulation of motivation. Journal of Educational Psychology, 90(2), 224.

Wolters, C. A., Pintrich, P. R., \& Karabenick, S. A. (2003). Assessing academic selfregulated learning. In Paper presented at the indicators of positive development: Definitions, measures, and prospective validity.

Wolters, C. A., \& Rosenthal, H. (2000). The relation between students' motivational beliefs and their use of motivational regulation strategies. International Journal of Educational Research, 33(7), 801-820.

Yew, E. H., \& Goh, K. (2016). Problem-based Learning: An overview of its process and impact on learning. Health Professions Education, 2(2), 75-79.

Zimmerman, B. J. (2008). Investigating self-regulation and Motivation: Historica background, methodological developments, and future prospects. American Educational Research Journal, 45(1), 166-183. https://doi.org/10.3102/ 0002831207312909. 